\title{
CANCER DIOGENES.
}

Q

\section{CHARACTER GENERICUS.}

Pedes octo (rarius fex aut decem;) infuper manus duæ chelatæ.

Palpi fex inæquales.

Oculi duo diftantes, plurimis pedunculati; elongati, mobiles.

Mandibula cornea, craffa.

Labium triplex.

Cauda articulata, inermis.

Lin. Syft. Nat. Gmel. p. 2963.

CHARACTER SPECIFICUS, Ëc.

CANCER MACROURUS PARASITICUS, chelis lævibus pubefcentibus: finiftra majore. Lin. Syft. Nat. p. 1049. Rumph. muf. t. 5. f. K. L.? Catef. Car. 2. t. 33. f. 1. 2.

Infectorum, quæ miro et fingulari modo formata complectitur genus Cancer, numerofiffimas fpecies in phalangas pro vario corporis habitu diftribuere prorfus neceffe eft, ut facilius dignofci poffint. E cancris nonnulli corpore brevi funt et quafi fubor- 
biculato, cujus diametros tranfverfa non raro longitudinem fuperat. Alii forma funt gracili et elongata; alii admodum fpinofi feu muricati; alii omnino læves. Sunt qui chelis maximis validifque armantur; funt etiam quorum pedes imbelles et in ermes. Aliis denique vafta eft et infignis magnitudo; aliorum mira tenuitas efficit ut fingulæ partes non nifi microfcopii ope fatis examinari poffint. Qure in hoc genere continentur animalia cruftas feu exuvias certis intervallis folent exuere; fub quod tempus artus gradatim contrahuntur et exiliores fiunt, ut e chelis reliquaque crufta facilius liberentur: quo facto, in latibulo quiefcit cancer paucos dies donec novum tegmen fatis induruerit, quod primo membranaceum potius eft quam cruftofum. Membrum amiffum, quod plerifque animalibus gravifimum foret et irreparabile, parum aut nihil queruntur cancri; paucis enim feptimanis excrefcit alterum novum et integrum. Immo quafi fcientes infeviffe iis naturam facultatem repullulandi, fi membrum aliquod læfum fuerit aut contufum, non expectant donec fanetur, fed fubito et violento nifu veluti impedimentum abjiciunt, et in locum tutum et quietum fe recipiunt, parte mox redintegrata gavifuri. Univerfo fere cancrorum generi mira ineft foecunditas; cujus infigne exemplum eft in illo qui Aftacus dicitur, unde duodecim millia ovorum fingulo partu excluduntur. Gulre dediti et animalibus et vegetabilibus vefcuntur. Cancer quem defcribimus inter eas fpecies militat qux crufta feu tegmine poftico deftituintur, quæque igitur teftas univalves, fi quas in litore invenerint vacuas et idonee formatas, 
tas, intrantes incolunt, corpore in teftam immerfo, chelis exertis. Cancrorum qui molles feu parafitici vocari folent præcipuæ fpecies funt Bernardus et Diogenes. Diogenem depinximus, qui plerumque teftam muricis, buccini, turbinis, vel neritæ inhabitat, unde et nomen adeptus eft, quod tefta eodem modo utatur quo celebris ifte pfeudo-philofophus dolio fuo. Figura prima monftrat animal tefta inclufum, fecúnda tefta exutum.

Nec prætereundum eft infigniter in cancris aberrare naturam a generali fuo confilio, quo cautum eft ut omnes corporis partes utrinque fibi invicem refpondeant. Ex illis enim multi chelas gerunt ab hoc latere immodicas, ab illo tenues et exiles; cogiturque cancer vocans et alii nonnulli brachium grande et incommodum inter ambulandum dorfo imponere. Notandum porro eft chelas magnas, quæ ut plurimum funt a dextro latere interdum effe a finiftro; quod idem teftis nonnullis univalvibus accidere notiffimum eft, quarum ora nunc dextrorfum nunc finiftrorfum fita funt. 


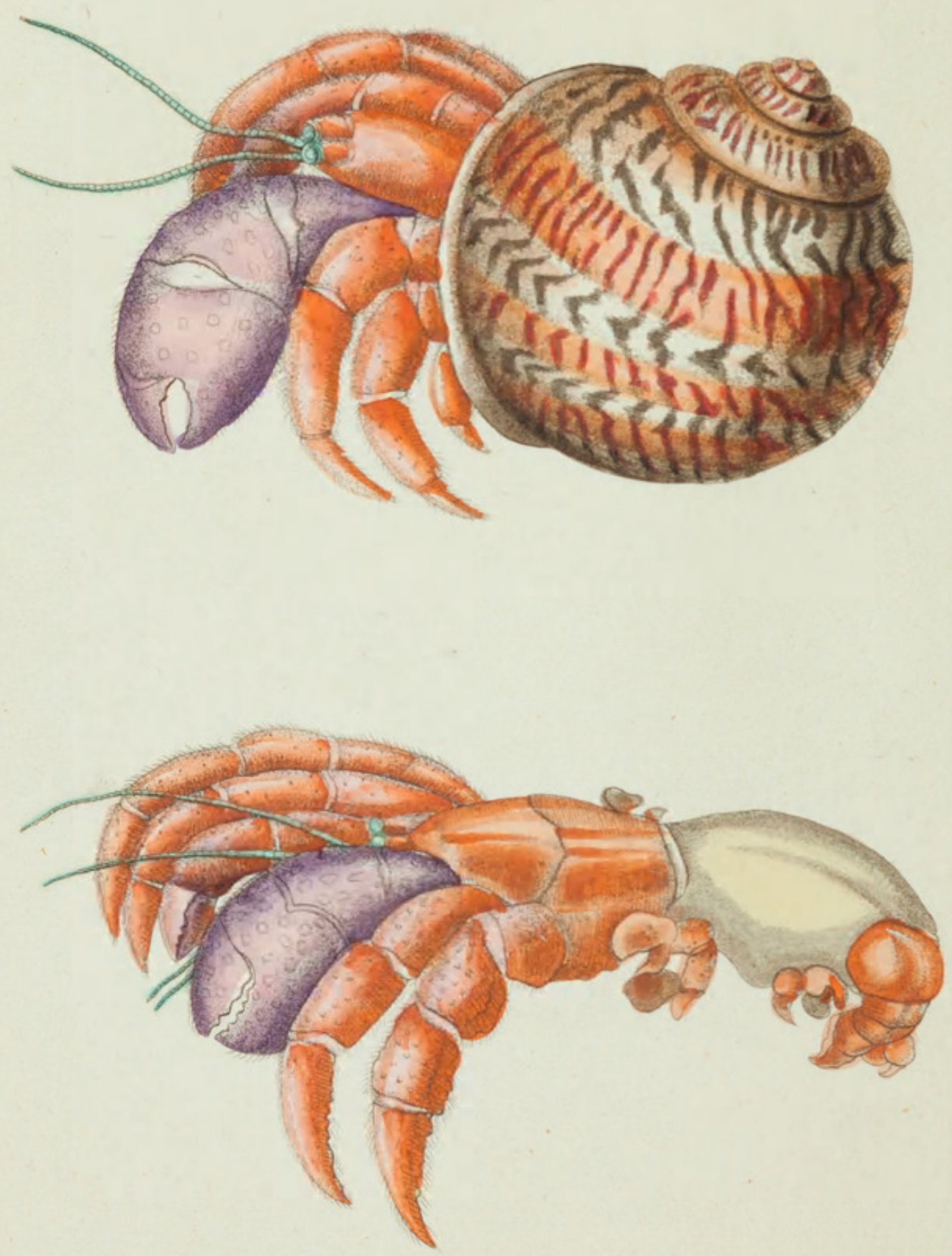

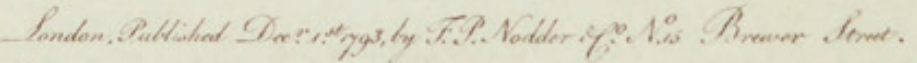




\section{T HE \\ D I O G E E S C R A B.}

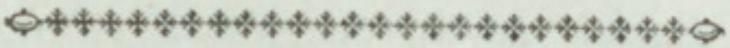

\section{GENERIC CHARACTER.}

Feet commonly eight, (in fome fpecies fix or ten) befides two chelated ones.

Palpi or Feelers fix, unequal.

Eyes two, diftant, in moft fpecies footfalked; elongated, moveable.

Mandible thick.

Lip triple.

Tail articulated, unarmed.

SPECIFIC CHARACTER, ËC.

ELONGATED PARASITIC CRAB, with fmooth pubefcent chelæ, of which the left is largeft.

THE INDIAN HERMIT-CRAB.

THE VIOLET-CLAWED HERMIT-CRAB.

The genus Cancer is diftinguifhed not more by the fingularly curious thape and appearance of the infects it contains, than by the vaft variety of fpe- 
cies into which it is divided; the number of which is fo great that it is found entirely neceffary to fubdivide them into fections according to their different thape or general habit, in order that they may the more readily be inveftigated. Some are of a fhort, thick, and nearly orbicular form, and fometimes the tranfverfe diameter of their body confiderably exceeds the longitudinal: others are of a thin and long form: fome are ftrongly muricated; others perfectly fmooth: fome are furnifhed with very ftrong and large chelæ or claws; others have only weak, unarmed feet: laftly, fome are remarkable for their great fize, while others are fo diminutive as to require the affiftance of glaffes in order to determine the ftructure of their feveral parts.

The animals of this genus caft their fhells from time to time. When this period approaches, the limbs gradually fhrink or wafte in fize, fo as to enable them to be drawn with the greater eafe from the claws and other parts of the fhell. The animal then lies in a quiet ftate for fome days, till the new thell is formed, or rather till it is hardened; for at firft it is rather membranaceous than cruftaceous. The lofs of a limb, an accident fo dreadful and irremediable to the major part of the animal world, is to thefe creatures of but little importance; fince the fpace of a few weeks fupplies the defect, and reftores them to their former ftate. What is ftill more wonderful, thefe animals, when injured, maimed, or bruifed on any particular limb, do not wait for the procefs of a gradual recovery of that individual part, but, as if confcious of the power of reproduction, 
production, voluntarily caft off with fudden violence the offending member, and betaking themfelves to a flate of retirement, await the formation of their new limb. Moft of the genus are very prolific animals. The female of the common Lobfter produces upwards of twelve thoufand eggs each time of laying. They are of a very voracious nature, and feed on animal as well as vegetable fubftances. The fpecies of cancer here reprefented is one of thofe which have the body naturally deftitute of a thelly covering; in confequence of which they never fail to take poffeffion of fuch vacant univalve fhells as happen to fuit their convenience; the body. being immerfed in the fhell, while the claws remain exferted. Amongft thefe parafitical or foft-bodied fpecies the two moft remarkable are the Cancer Bernardus and the Cancer Diogenes. It is the latter of thefe which is figured on the prefent plate $e_{s}$ the firft figure thewing the animal in the fhell, the fecond reprefenting it divefted of its covering. It is generally found inhabiting the fhell of a Murex, Buccinum, Turbo, or Nerite, and has obtained the title of Diogenes from its refiding in this convenient receptacle as that celebrated pfeudo-philofopher is reported to have done in his tub.

I fhould not difmifs this article without obferving that the genus cancer affords a curious example of deviation from that, general fymmetry of parts fo confpicuous in moft other animals; in which the thape of the body and limbs on one fide exactly correfponds to that of the other. Many of the Cancri, however, are furnifhed with a pair of chelæ 
on one fide of immoderate fize, while thofe of the oppofite fide are thin and fmall; and in fome particular fpecies, as the C: vocans, \&c., the fize of the large arm is fo great as to oblige the animal to fupport it on its back, in which pofition it is generally placed while the creature is walking. It may likewife be added that this is a particularity which is fometimes reverfed; a circumftance which takes place, as is well known, in the univalve fhells. 


\section{$2 \mathrm{BHL}$ Biodiversity Heritage Library}

Shaw, George. 1793. "The Diogenes Crab, Cancer diogenes [PI. 160]." The Naturalist's Miscellany 5(LII), https://doi.org/10.5962/p.310739.

View This Item Online: https://www.biodiversitylibrary.org/item/276340

DOI: https://doi.org/10.5962/p.310739

Permalink: https://www.biodiversitylibrary.org/partpdf/310739

\section{Holding Institution}

Museums Victoria

\section{Sponsored by}

Atlas of Living Australia

\section{Copyright \& Reuse}

Copyright Status: Public domain. The BHL considers that this work is no longer under copyright protection.

This document was created from content at the Biodiversity Heritage Library, the world's largest open access digital library for biodiversity literature and archives. Visit BHL at https://www.biodiversitylibrary.org. 